Науковий вісник Нлту України
Scientific Bulletin of UNFU
https://nv.nltu.edu.ua
https://doi.org/10.36930/40300413
Article received 17.09.2020 p.
Article accepted 02.09.2020 p.
UDC 630.[182+187]

А. А. Новак, С. Л. Копій, І. В. Фізик

Національний лісотехнічний університет Украӥни, м. Львів, Украӥна

\title{
АНАЛІЗ ЛІСОТАКСАЦІЙНОЇ СТРУКТУРИ ДУБОВИХ ЛІСОСТАНІВ ЗАХІДНОГО ЛІСОСТЕПУ
}

\begin{abstract}
Проаналізовано особливості поширення дубових деревостанів у Західному Лісостепу України. Здійснено аналіз лісотипологічної структури деревостанів за участю дуба звичайного (Quercus robur L.) в умовах Західноукраїнського лісостепового лісогосподарського округу. Досліджено структуру площ дубових лісостанів у розрізі едатопів та типів лісу, вивчено їх бонітетну та повнотну структуру, склад та походження. Встановлено, що найбільша частка дубових лісостанів Західного Лісостепу зосереджена у грудових умовах - 79,3\%. Сугрудові типи лісорослинних умов становлять 20,5\% від площі дубових лісостанів. За ступенем зволоження грунтів, дуб звичайний, на теренах Західноукраїнського лісостепового лісогосподарського округу, віддає перевагу свіжим умовам, де зосереджено 65,6 \% дубових лісостанів регіону. Встановлено, що у досліджуваному регіоні дуб звичайний бере участь у формуванні 47 типів лісу, з них у 19 виступає як типотвірна порода. Більшість дубових деревостанів має I клас бонітету $(49,9 \%)$ і значна частина $(35,7 \%)$ насаджень - II. Середній бонітет становить I,3. Дубові деревостани у Західному Лісостепу, в основній масі, є середньоповнотними. Їх середня повнота становить 0,73 . Найбільша частка $(39,3 \%)$ приурочена до повноти 0,7 . Частка середньоповнотних деревостанів загалом становить 55,9 \% від площі дубових лісів досліджуваного регіону. Питома вага високоповнотних насаджень у повнотній структурі дубових лісостанів Західноукраїнського лісостепового лісогосподарського округу становить 42,3\%. Виявлено, що у дубових лісостанах Західного Лісостепу за складом переважають насадження, де дуба у складі тільки 4 одиниці - $20 \%$ від загальної площі. Середній коефіцієнт участі дуба у складі насаджень - 5,7. Вікова структура дубових лісів Західного Лісостепу є нерівномірною, із значною перевагою середньовікових деревостанів - 54,2 \%. Стиглі деревостани займають тільки 8,0 \% площі дубових лісів Західного Лісостепу. Середній вік дубових лісостанів Західноукраїнського лісостепового лісогосподарського округу - 61,2 років. 3'ясовано, що у досліджуваному регіоні переважають $(69,5 \%)$ штучні насадження, створені, зазвичай, садінням лісових культур. Природні насінні дубові деревостани становлять 27,3 \% від площі дубових лісів Західного Лісостепу, деревостани вегетативного природного походження $-3,2 \%$.
\end{abstract}

Ключові слова: дуб звичайний; лісотипологічна структура; лісотаксаційні характеристики; типи лісу; походження.

\section{Вступ}

Дубові ліси в лісовому господарстві України є одними 3 найбільш поширених та цінних $з$ економічної точки зору, а їх експлуатація завжди була пріоритетною в господарській діяльності. Дуб звичайний (Quercus robur L.) є однією з найцінніших деревних порід, що ростуть на території України та у межах досліджуваного регіону. Насадження за його участю, поряд 3 високою сировинною цінністю, виконують надзвичайно важливі грунтозахисні, водорегулювальні, водоохоронні та рекреаційні функції [5].

Незважаючи на сьогоднішню невизначеність щодо основних принципів ринкового господарювання, потреба у високоцінних дубових сортиментах для господарських і промислових цілей залишається доволі відчутною і гострою не тільки в Україні, але й далеко за ії межами. Набутий багаторічний досвід переконливо засвідчує, що традиційні методи господарювання 3 акцен- том на суцільні рубки та наступне паросткове поновлення чи створення лісових культур не змогли реалізувати ідею розширеного відтворення високопродуктивних та стійких дубових лісостанів.

Негативні екологічні та нерегульовані антропогенні чинники призвели до зменшення захисної ролі лісів, зокрема у Західному регіоні України, порушення їх вікової структури, погіршення породного складу лісів. Питома вага пристигаючих соснових, дубових, букових лісів у віковій структурі державного лісового фонду становить тепер 9-10\%, тоді як за лісівничими нормами вона повинна становити $20 \%$ [3]. 3 огляду на це, лісостани за участю дуба звичайного на території Західного Лісостепу є цінною лісовою формацією в лісовому фонді України.

Ведення лісового господарства, насамперед на лісівничій основі, є запорукою успіху у вирощуванні та формуванні насаджень, що повною мірою відповідають по-

Інформація про авторів:

Новак Анатолій Анатолійович, канд. с.-г. наук, доцент, кафедра лісівництва. Email: novak@gmail.com; https://orcid.org/0000-0003-1239-7423

Копій Сергій Леонідович, канд. с.-г. наук, доцент, кафедра лісівництва. Email: s.kopiy@email.ua; https://orcid.org/0000-0002-7322-7244

Фізик Ігор Васильович, канд. с.-г. наук, доцент, докторант, кафедра екологіï. Email: igor240265@gmail.com; https://orcid.org/0000-0003-4247-2519

Цитування за Дсту: Новак А. А., Копій С. Л., Фізик І. В. Аналіз лісотаксаційної структури дубових лісостанів Західного Лісостепу. Науковий вісник НЛтУ України. 2020, т. 30, № 4. С. 73-78.

Citation APA: Novak, A. A., Kopiy, S. L., \& Fizyk, I. V. (2020). Forest taxation structure of oak forest stands of the Western Forest Steppe. Scientific Bulletin of UNFU, 30(4), 73-78. https://doi.org/10.36930/40300413 
родному складу природних лісостанів. Вивчення лісотипологічної та лісотаксаційної складових під час формування та вирощування високопродуктивних, біологічно стійких лісів, зокрема дубових, у Західному Лісостепу, є необхідним та обов'язковим.

Об'єкт дослідження - лісостани за участю дуба звичайного, що зростають на території Західноукраїнського лісостепового лісогосподарського округу та належать до Державного лісового фонду України.

Предмет дослідження - типологічна різноманітність та лісівничо-таксаційні показники лісостанів за участю дуба звичайного в лісовому фонді Західноукраїнського лісостепового лісогосподарського округу.

Мета дослідження - проаналізувати особливості структури та основні лісотаксаційні показники дубових деревостанів у Західному Лісостепу України.

Для досягнення зазначеної мети потрібно виконати такі основні завдання дослідження:

- проаналізувати умови росту дубових лісостанів Західноукраїнського лісостепового лісогосподарського округу, охарактеризувати їх з лісотипологічної точки зору.

- здійснити структурний розподіл дубових насаджень Західного Лісостепу за основними лісотаксаційними характеристиками.

- на основі проведеного аналізу зробити відповідні висновки щодо лісотипологічної та лісотаксаційної структури дубових лісостанів Західного Лісостепу.

Наукова новизна отриманих результатів дослідження: вперше для умов Західноукраїнського лісостепового лісогосподарського округу проаналізовано структуру лісостанів за участю дуба звичайного в розрізі їх бонітету, повноти, складу, віку та походження. Уточнено дані щодо поширення дуба звичайного у різних типах лісу у Західному Лісостепу.

Практична значущість результатів дослідження. Виконаний аналіз дає змогу забезпечити комплексний та збалансований підхід до ведення господарства в дубових лісах та багатоцільове використання лісових ресурсів Західного Лісостепу

Аналіз останніх досліджень та публікацій. Деревостани лісостепової зони України, насамперед дубові, досить детально вивчили вітчизняні вчені у різноманітних лісівничих та екологічних аспектах. Так, лісорослинний потенціал дубових лісів, їх поширення та продуктивність досліджували В. П. Ткач, О.В.Кобець, М. Г. Румянцев [17, 18, 19], Л. І. Копій [4, 5, 6], А. О. Бондар, В. Д. Вакулюк, О. М. Орлов [1, 2]. Особливості стану та здійснення лісогосподарських заходів у дубових лісах Лівобережного Лісостепу вивчала В. Л. Мєшкова [10]. Динаміку та закономірності відновлення дібров у південній частині Правобережного Лісостепу досліджували С. Є. Сендонін [13, 14, 15] М. Г. Румянцев, В. А. Солодовник, В. П. Чигринець
$[12,11]$, у північній його частині - В. В. Левченко [7, 8, 9]. Однак у Західному Лісостепу дослідження лісотипологічної та лісотаксаційної структури дубових деревостанів $є$ актуальними, позаяк слугують відправною точкою для лісотипологічного підходу до ведення лісового господарства та визначення режиму лісокористування.

Матеріали та методи дослідження. Для аналізу лісового фонду дуба звичайного в умовах Західного Лісостепу використано матеріали лісовпорядкування лісогосподарських підприємств, які є структурними одиницями Хмельницького, Тернопільського та Львівського обласних управлінь лісового і мисливського господарства, станом на 01.01.2013 р. Для характеристики лісового фонду дуба звичайного на території рівнинної частини Львівської області, було опрацьовано матеріали лісовпорядкування лісогосподарських підприємств, що належать до ії лісостепової зони, а саме: ДП "Бібрське ЛГ", ДП "Бродівське ЛГ", ДП "Золочівське ЛГ", ДП "Львівське ЛГ", ДП "Жовківське ЛГ", ДП "Радехівське ЛГ", ДП "Рава-Руське ЛГ", ДП "Стрийське ЛГ", ДП "Буське ЛГ", ДП "Львівський ЛСНЦ". Загалом, було проаналізовано матеріали лісовпорядкування 25-ти лісогосподарських підприємств у межах Західноукраїнського лісостепового лісогосподарського округу, загальна площа яких становить понад 211 тис. га.

\section{Результати дослідження та їх обговорення}

Поширення та продуктивність дубових лісостанів значною мірою визначається типами лісорослинних умов. Наприклад, дуб звичайний у Західному Лісостепу України поширений у трьох трофотопах: суборах, сугрудах і грудах (табл. 1). Найбільша частка дубових лісостанів зосереджена у найбагатших умовах - грудових. Площа дубових насаджень тут становить 167778,3 га, або 79,3 \% від площі дубових лісів Західноукраїнського лісостепового лісогосподарського округу. У сугрудових типах лісорослинних умов площа дубових лісостанів істотно менша і становить 43355,3 га, або $20,5 \%$. У відносно бідних умовах - суборах, дуб звичайний, через свої біоекологічні особливості, росте в насадженнях у ролі типологічної домішки і займає 573,6 га, або 0,3 \% від загальної площі дубових лісів Західного Лісостепу.

За ступенем зволоження грунтів дуб звичайний в лісостанах Західноукраїнського лісостепового лісогосподарського округу найпоширеніший у свіжих гігротопах. Його частка в цих умовах явно переважає інші породи і становить 65,6 \% від площі дубових деревостанів регіону. Вологі гігротопи є менш поширеними, тому й становлять всього $33,6 \%$.

Табл. 1. Розподіл дубових лісостанів Західного Лісостепу за едатопами

\begin{tabular}{|c|c|c|c|c|c|c|}
\hline \multirow{2}{*}{ Трофотоп } & \multirow{2}{*}{ Од. виміру } & \multicolumn{4}{|c|}{ Гігротоп } & \multirow{2}{*}{$\sum$ по трофотопу } \\
\hline & & 1 & 2 & 3 & 4 & \\
\hline \multirow{2}{*}{ B } & га & 29,3 & 241,0 & 288,5 & 14,8 & 573,6 \\
\hline & $\%$ & 0,0 & 0,1 & 0,1 & 0,0 & 0,3 \\
\hline \multirow{2}{*}{$\mathrm{C}$} & га & 234,5 & 13717,6 & 29030,0 & 373,2 & 43355,3 \\
\hline & $\%$ & 0,1 & 6,5 & 13,7 & 0,2 & 20,5 \\
\hline \multirow{2}{*}{ D } & га & 436,9 & 124864,7 & 41762,2 & 714,5 & 167778,3 \\
\hline & $\%$ & 0,2 & 59,0 & 19,7 & 0,3 & 79,3 \\
\hline \multirow{2}{*}{$\sum$ по гігротопу } & га & 700,7 & 138823,3 & 71080,7 & 1102,5 & 211707,2 \\
\hline & $\%$ & 0,3 & 65,6 & 33,6 & 0,5 & 100,0 \\
\hline
\end{tabular}




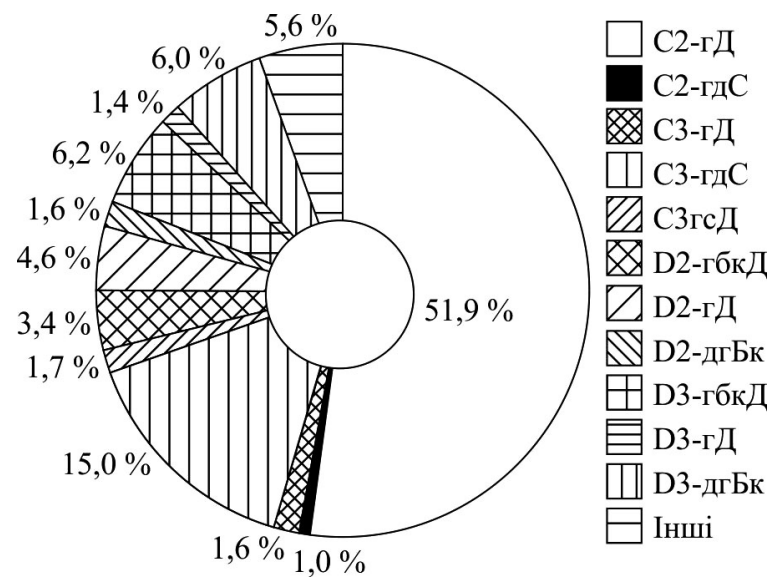

Рисунок. Розподіл дубових лісостанів Західного Лісостепу за типами лісу (\%)

Найбільшими за площею типами лісу, які в умовах Західного Лісостепу формують деревостани за участю дуба звичайного, є свіжа грабова діброва - 109880,5 га $(51,9 \%)$, волога грабова діброва - 31774,2 га $(15,0 \%)$, дещо меншою мірою поширені волога грабова судібро- ва - 13206,1 га $(6,2 \%)$, волога грабово-соснова судіброва - 12742,9 га $(6,0 \%)$, свіжа грабово-букова діброва 11890,3 га (5,6 \%), свіжа грабова судіброва - 9752,8 га $(4,6 \%)$. Найменшими за площею є волога дубово-грабова бучина - 3599,1 га (1,7 \%), волога грабово-букова діброва - 3454,4 га (1,6 \%), свіжий та вологий грабоводубово-сосновий сугруд - 3325,3 га $(1,6 \%)$ та 2861,1 га $(1,4 \%)$ відповідно, а також свіжа дубово-грабова бучина - 2014,5 га (1,0 \%) (рисунок). Типи лісу, площа яких становить менше $1 \%$, ми виділили в окрему категорію "інші" і частка їх сукупно становить 7206 га, або 3,4 \% площі дубових лісів регіону.

У дев'ятнадцяти типах лісу дуб звичайний виступає як основна типотвірна порода (196488,7 га/92,8 \%), у вісімнадцяти типах - як характерна типологічна домішка (13194,7 га/6,2 \%). Водночас в умовах Західного Лісостепу дуб росте також у типах лісу, що формуються іншими породами (сосною, буком, ялицею, вільхою), де утворює похідні деревостани загальною площею 2023,8 га (1,0 \%) (табл. 2).

Табл. 2. Розподіл дубових деревостанів Західного Лісостепу за типотвірною функцією (в розрізі типів лісу)

\begin{tabular}{|c|c|c|c|c|}
\hline \multirow{2}{*}{$\begin{array}{c}\text { № } \\
\text { 3/ח } \\
\end{array}$} & \multicolumn{2}{|l|}{ Тип лісу } & \multicolumn{2}{|c|}{ Площа } \\
\hline & назва & індекс & га & $\%$ \\
\hline \multicolumn{5}{|c|}{ Типи лісу, сформовані дубом, як типотвірною породою } \\
\hline 1 & Свіжа грабово-букова судіброва & $\mathrm{C}_{2}$-гбкД & 88,0 & 0,04 \\
\hline 2 & Свіжа грабова судіброва & $\mathrm{C}_{2}$-гД & 9752,8 & 4,61 \\
\hline 3 & Свіжа грабово-соснова судіброва & $\mathrm{C}_{2}$-гсД & 284,7 & 0,13 \\
\hline 4 & Волога грабово-букова судіброва & $\mathrm{C}_{3}-г б к Д$ & 186,6 & 0,09 \\
\hline 5 & Волога грабова судіброва & $\mathrm{C}_{3}$-гД & 13206,1 & 6,24 \\
\hline 6 & Ворога грабово-соснова судіброва & $\mathrm{C}_{3}$-гсД & 12742,9 & 6,02 \\
\hline 7 & Волога ялицева судіброва & $\mathrm{C}_{3}$-яцД & 2,3 & 0,00 \\
\hline 8 & Сира грабова судіброва & $\mathrm{C}_{4}$-гД & 227,8 & 0,11 \\
\hline 9 & Сира судіброва & $\mathrm{C}_{4}-$ Д & 23,1 & 0,01 \\
\hline 10 & Суха грабова діброва & $\mathrm{D}_{1}$-гД & 436,9 & 0,21 \\
\hline 11 & Свіжа грабово-букова діброва & $\mathrm{D}_{2}$-гбкД & 11890,3 & 5,62 \\
\hline 12 & Свіжа грабова діброва & $\mathrm{D}_{2}-\Gamma Д$ & 109880,5 & 51,90 \\
\hline 13 & Волога букова діброва & $\mathrm{D}_{3}$-бкД & 1719,1 & 0,81 \\
\hline 14 & Волога грабово-букова діброва & $\mathrm{D}_{3}$-гбкД & 3454,4 & 1,63 \\
\hline 15 & Волога грабова діброва & $\mathrm{D}_{3}-\Gamma Д$ & 31774,2 & 15,01 \\
\hline 16 & Волога ясенова діброва & $\mathrm{D}_{3}$-ясД & 200,1 & 0,09 \\
\hline 17 & Волога ялицева діброва & $\mathrm{D}_{3}$-яцД & 2,2 & - \\
\hline 18 & Сира грабова діброва & $\mathrm{D}_{4}$-гД & 612,6 & 0,29 \\
\hline 19 & Сира ясенова діброва & $\mathrm{D}_{4}$-ясД & 4,1 & 0,00 \\
\hline & Всього & - & 196488,7 & 92,81 \\
\hline \multicolumn{5}{|c|}{ Типи лісу, сформовані за участю дуба, як типологічної домішки } \\
\hline 1 & Сухий дубово-сосновий субір & $\mathrm{B}_{1-д \mathrm{C}}$ & 1,2 & - \\
\hline 2 & Сухий дубово-ялиновий субір & $\mathrm{B}_{1}$-дЯл & 28,1 & 0,01 \\
\hline 3 & Свіжий дубово-сосновий субір & $\mathrm{B}_{2}-$-д & 241,0 & 0,11 \\
\hline 4 & Вологий дубово-сосновий субір & $\mathrm{B}_{3}-д \mathrm{C}$ & 288,5 & 0,14 \\
\hline 5 & Сирий дубово-сосновий субір & $\mathrm{B}_{4}-$ - $\mathrm{C}$ & 14,8 & 0,01 \\
\hline 6 & Сухий дубово-ялиновий сугруд & $\mathrm{C}_{1}$-дЯл & 234,5 & 0,11 \\
\hline 7 & Свіжа грабово-дубова субучина & $\mathrm{C}_{2}$-гдБк & 186,6 & 0,09 \\
\hline 8 & Свіжий грабово-дубово-сосновий сугруд & $\mathrm{C}_{2}$-гдС & 3325,3 & 1,57 \\
\hline 9 & Свіжа дубово-грабова субучина & $\mathrm{C}_{2}$-дгБк & 52,9 & 0,02 \\
\hline 10 & Вологий грабово-дубово-сосновий сугруд & $\mathrm{C}_{3}$-гдС & 2861,1 & 1,35 \\
\hline 11 & Волога дубово-грабова субучина & $\mathrm{C}_{3}$-дгБк & 31,0 & 0,01 \\
\hline 12 & Сирий грабово-дубово-сосновий сугруд & $\mathrm{C}_{4}$-гдС & 36,1 & 0,02 \\
\hline 13 & Сирий дубово-сосновий сугруд & $\mathrm{C}_{4}$-дC & 2,9 & - \\
\hline 14 & Свіжа грабово-дубова бучина & $\mathrm{D}_{2}$-ГдБк & 1,2 & - \\
\hline 15 & $\begin{array}{l}\text { Свіжий грабово-дубово-сосновий груд (за даними матеріалів лі- } \\
\text { совпорядкування) }\end{array}$ & $\mathrm{D}_{2}$-гдС & 20,2 & 0,01 \\
\hline 16 & Свіжа дубово-грабова бучина & $\mathrm{D}_{2}$-дгБк & 2014,5 & 0,95 \\
\hline 17 & Волога дубово-грабова бучина & $\mathrm{D}_{3}$-дгБк & 3599,1 & 1,70 \\
\hline 18 & Волога дубова яличина & $\mathrm{D}_{3}$-дЯц & 255,7 & 0,12 \\
\hline & Всього & - & 13194,7 & 6,23 \\
\hline
\end{tabular}




\begin{tabular}{|c|c|c|c|c|}
\hline \multicolumn{5}{|c|}{ Типи лісу інших порід, зайняті похідними дубовими лісостанами } \\
\hline 1 & Свіжий грабово-буково-сосновий сугруд & $\mathrm{C}_{2}-$-ГкК & 27,3 & 0,01 \\
\hline 2 & Сирий чорновільховий сугруд & $\mathrm{C}_{4}$-Влч & 83,3 & 0,04 \\
\hline 3 & Свіжа грабова бучина & $\mathrm{D}_{2}$-ГБК & 1058,0 & 0,50 \\
\hline 4 & Волога буково-смерекова яличина & $\mathrm{D}_{3}$-бксмЯц & 30,4 & 0,01 \\
\hline 5 & Волога букова яличина & $\mathrm{D}_{3}$-бкЯц & 48,7 & 0,02 \\
\hline 6 & Волога грабова бучина & $\mathrm{D}_{3}$-ГБК & 321,5 & 0,15 \\
\hline 7 & Волога грабово-букова яличина & $\mathrm{D}_{3}$-ГбкЯц & 321,9 & 0,15 \\
\hline 8 & Волога грабово-ялицева бучина & $\mathrm{D}_{3}$-ГяцБк & 10,7 & 0,01 \\
\hline 9 & Волога ялицева бучина & $\mathrm{D}_{3}$-яцБк & 24,2 & 0,01 \\
\hline 10 & Сирий чорновільховий груд & $\mathrm{D}_{4}$-Влч & 97,8 & 0,05 \\
\hline \multirow{2}{*}{\multicolumn{2}{|c|}{ Всього }} & - & 2023,8 & 0,96 \\
\hline & & - & 211707,2 & 100,00 \\
\hline
\end{tabular}

Бонітетна структура дубових лісостанів Західного Лісостепу свідчить про їх високу продуктивність та якість. Середній бонітет тут становить I,3 (табл. 3). Більшість дубових деревостанів має I клас бонітету $(49,9 \%)$ і значна частина $(35,7 \%)$ насаджень - II. $9 \%$ насаджень сягають $\mathrm{I}^{\mathrm{a}}$, а $0,7 \%$ (1501,9 га) і $\mathrm{I}^{6}$ бонітету. Деревостани вищих класів бонітету також присутні в загальній структурі, проте площі їх незначні. Насадження III класу бонітету становлять $4,4 \%$ і розповсюджені на площі 9274,2 га. Незначна частка $(0,2 \%)$ припадає на насадження IV класу бонітету. Деревостани V і нижче класів бонітету практично відсутні.

Загалом, у Західному Лісостепу умови росту дубових деревостанів близькі до оптимальних, що дає змогу максимально реалізувати лісорослинний потенціал лісових ділянок.

Деревостани за участю дуба звичайного у Західному Лісостепу, в основній масі, $є$ середньоповнотними. Їх середня повнота становить 0,73 (табл. 4). Найбільша площа дубових насаджень (понад 8150 га, або 39,3\%) приурочена до повноти 0,7. Загалом, середньоповнотні деревостани становлять 55,9 \% площі дубових лісів досліджуваного регіону. Питома вага високоповнотних насаджень у повнотній структурі дубових лісостанів Західноукраїнського лісостепового лісогосподарського округу становить $42,3 \%$, переважна частина яких $(32,9 \%)$ - деревостани 3 повнотою 0,8. Низька зімкнутість намету характерна тільки для 1,8 \% насаджень.

Розподіл дубових деревостанів Західного Лісостепу за складом свідчить про перевагу насаджень, де дуба у складі тільки 4 одиниці - $20 \%$ від загальної площі (табл. 5). Середній коефіцієнт участі дуба у складі насаджень - 5,7. Значними площами також відзначаються насадження із коефіцієнтом складу 3Д (13,3\%), 5Д $(16,1 \%)$ та 6 Д $(14,5 \%)$, дещо нижчими - 7Д $(11,6 \%)$. Чисті дубові деревостани становлять 7,7\% від площі дубових лісів Західного Лісостепу.

Вікова структура дубових лісів Західного Лісостепу $\epsilon$ нерівномірною, із значною перевагою середньовікових деревостанів - 54,2 \% (табл. 6). Значно менш розповсюджені молодняки та пристигаючі насадження 21,3 та 15,8 \% відповідно. Стиглі деревостани займають $8,0 \%$ від площі дубових лісів Західного Лісостепу. Найменшу площу займають перестійні деревостани 0,7\%. Середній вік дубових лісостанів Західноукраїнського лісостепового лісогосподарського округу 61,2 роки.

Розподіл дубових лісостанів Західноукраїнського лісостепового лісогосподарського округу за походженням свідчить про значну перевагу $(69,5 \%)$ штучних насаджень, створених, зазвичай, садінням лісових культур (табл. 7). Природні насінні дубові деревостани становлять 27,3\% від площі дубових лісів Західного Лісостепу, деревостани вегетативного природного походження $-3,2 \%$

3 наведених вище табличних даних видно, що у дубових лісостанах Західного Лісостепу за складом переважають насадження, де дуба у складі тільки 4 одиниці - 20 \% від загальної площі.

Табл. 3. Розподіл площ дубових лісостанів Західного Лісостепу за класами бонітету

\begin{tabular}{|c|c|c|c|c|c|c|c|c|c|c|c|c|}
\hline \multirow{2}{*}{ Показник } & \multicolumn{10}{|c|}{ Клас бонітету } & \multirow[b]{2}{*}{$\sum$} & \multirow{2}{*}{$\begin{array}{l}\text { Серед } \\
\text { боніт. }\end{array}$} \\
\hline & $\mathrm{I}^{\mathrm{\Gamma}}$ & $\mathrm{I}^{\mathrm{B}}$ & $I^{6}$ & $\mathrm{I}^{\mathrm{a}}$ & $\mathrm{I}$ & II & III & IV & $\mathrm{V}$ & $\mathrm{V}^{\mathrm{a}}$ & & \\
\hline га & 9,4 & - & 1501,9 & 19118,7 & 105636 & 75506,6 & 9247,2 & 477,7 & 99,3 & 37,4 & 211707,2 & 13 \\
\hline$\%$ & - & - & 0,7 & 9,0 & 49,9 & 35,7 & 4,4 & 0,2 & - & - & 100,0 & , \\
\hline
\end{tabular}

Табл. 4. Розподіл площ дубових лісостанів Західного Лісостепу за повнотою

\begin{tabular}{|c|c|c|c|c|c|c|c|c|c|c|}
\hline \multirow{2}{*}{ Показник } & \multicolumn{9}{|c|}{ Повнота } & \multicolumn{2}{c|}{\begin{tabular}{c} 
Серед. \\
\cline { 2 - 11 }
\end{tabular}} & $\leq 0,3$ & 0,4 & 0,5 & 0,6 & 0,7 & 0,8 & 0,9 & 1,0 & 211707,2 & \multirow{2}{*}{0,73} \\
\hline га & 1008,8 & 2650,2 & 8585,2 & 26682,6 & 83150,5 & 69731,7 & 18681,7 & 1216,5 & 2100 \\
\hline$\%$ & 0,5 & 1,3 & 4,1 & 12,6 & 39,3 & 32,9 & 8,8 & 0,6 & 100,0 & \\
\hline
\end{tabular}

Табл. 5. Розподіл площ дубових лісостанів Західного Лісостепу за часткою дуба у складі

\begin{tabular}{|c|c|c|c|c|c|c|c|c|c|c|c|c|}
\hline \multirow{2}{*}{ Показник } & \multicolumn{10}{|c|}{ Коефіцієнт складу } & \multirow{2}{*}{$\sum$} & \multirow{2}{*}{$\begin{array}{c}\text { Серед. } \\
\text { коеф. } \\
\text { складу }\end{array}$} \\
\hline & 1д & 2Д & ЗД & 4Д & 5Д & 6Д & 7Д & 8Д & 9Д & 10Д & & \\
\hline га & 834,5 & 4926,2 & 28114,6 & 42298,5 & 34101,5 & 30743,3 & 24472,2 & 19318,8 & 10499,1 & 16398,5 & 211707,2 & \\
\hline$\%$ & 0,4 & 2,3 & 13,3 & 20,0 & 16,1 & 14,5 & 11,6 & 9,1 & 5,0 & 7,7 & 100,0 & 5,1 \\
\hline
\end{tabular}

Табл. 6. Розподіл площ дубових лісостанів Західного Лісостепу за групами віку

\begin{tabular}{|c|c|c|c|c|c|c|c|c|}
\hline Показник & $\begin{array}{c}\text { Молодняки I } \\
\text { класу }\end{array}$ & $\begin{array}{c}\text { Молодняки II } \\
\text { класу }\end{array}$ & $\begin{array}{c}\text { Середньові- } \\
\text { кові }\end{array}$ & Пристигаючі & Стиглі & Перестійні & $\begin{array}{c}\sum \\
\text { (рер.) }\end{array}$ \\
\hline га & 18384,1 & 26763,8 & 114654 & 33484,3 & 16938 & 1483 & 211707,2 & 61,2 \\
\hline$\%$ & 8,7 & 12,6 & 54,2 & 15,8 & 8,0 & 0,7 & 100,0 & 6 \\
\hline
\end{tabular}


Табл. 7. Розподіл площ дубових лісостанів Західного Лісостепу за походженням

\begin{tabular}{|c|c|c|c|c|c|}
\hline Показник & Насінне природне & Насінне штучне & Вегетативне природне & Вегетативне штучне & $\sum$ \\
\hline га & 57794,3 & 147214,2 & 6697,7 & 1,0 & 211707,2 \\
\hline$\%$ & 27,3 & 69,5 & 3,2 & 0,0 & 100,0 \\
\hline
\end{tabular}

Водночас, середній коефіцієнт участі дуба у складі насаджень - 5,7. Вікова структура дубових лісів Західного Лісостепу є нерівномірною, із значною перевагою середньовікових деревостанів - 54,2\%. Стиглі деревостани займають тільки 8,0 \% площі дубових лісів Західного Лісостепу. Середній вік дубових лісостанів Західноукраїнського лісостепового лісогосподарського округу - 61,2 років. У досліджуваному регіоні переважають штучні насадження $(69,5 \%)$, створені, зазвичай, садінням лісових культур. Природні насінні дубові деревостани становлять 27,3 \% від площі дубових лісів Західного Лісостепу, деревостани вегетативного природного походження - 3,2\%.

\section{Висновки}

1. В умовах Західного Лісостепу дуб звичайний поширений у трьох трофотопах: суборах, сугрудах і грудах. Найбільша частка $(79,3 \%)$ дубових лісостанів зосереджена у грудових умовах. За ступенем зволоження грунтів дуб звичайний у лісостанах Західного Лісостепу найпоширеніший у свіжих гігротопах. Його частка в цих умовах становить 65,6\% від площі дубових деревостанів лісогосподарського округу.

2. Найпоширенішими типами лісу в досліджуваному регіоні є свіжа грабова діброва $\left(\mathrm{D}_{2}-г Д\right)-51,9 \%$, волога грабова діброва $\left(\mathrm{D}_{3}-\right.$-г $-15,0 \%$. У ролі основної типотвірної породи, дуб звичайний зростає у 19-ти типах лісу, найпоширенішим 3 яких $є$ свіжа грабова діброва $\left(\mathrm{D}_{2}\right.$-гД) - 51,9\% від площі дубових лісостанів. У 18-ти типах лісу дуб зростає у ролі характерної типологічної домішки, найпоширенішим 3 яких є волога дубово-грабова бучина $\left(\mathrm{D}_{3}\right.$-дгБк $)$ - 1,7 \% площі. У 10-ти типах лісу дуб звичайний формує похідні деревостани, найістотнішим за площею з яких $\epsilon$ свіжа грабова бучина $\left(\mathrm{D}_{2}-\right.$ гБк) $-0,5 \%$ площі.

3. Більшість дубових деревостанів має I клас бонітету $(49,9 \%)$ і значна частина $(35,7 \%)$ насаджень - II. Cередній бонітет становить I,3.

4. Дубові деревостани у Західному Лісостепу, в основній масі, $є$ середньоповнотними. Їх середня повнота становить 0,73 . Найбільша частка $(39,3 \%)$ приурочена до повноти 0,7. Середньоповнотні деревостани загалом становлять 55,9 \% від площі дубових лісів досліджуваного регіону. Питома вага високоповнотних насаджень у повнотній структурі дубових лісостанів Західноукраїнського лісостепового лісогосподарського округу становить $42,3 \%$.

5. За складом переважають насадження, де дуба у складі тільки 4 одиниці - 20 \% від загальної площі. Середній коефіцієнт участі дуба у складі насаджень - 5,7.

6. Вікова структура дубових лісів Західного Лісостепу є нерівномірною, із значною перевагою середньовікових деревостанів - 54,2\%. Стиглі деревостани займають тільки 8,0 \% площі дубових лісів Західного Лісостепу. Середній вік дубових лісостанів Західноукраїнського лісостепового лісогосподарського округу - 61,2 роки.

7. У досліджуваному регіоні переважають $(69,5 \%)$ штучні насадження. Природні насінні дубові деревостани становлять 27,3\% від площі дубових лісів Західного Лісостепу, деревостани вегетативного природного походження $-3,2 \%$.

\section{References}

1. Bondar, A. O. (2004). Osoblyvosti rostu osnovnykh lisoutvoriuvalnykh derevnykh porid Vinnychchyny. Ahrarna osvita i nauka, 5(1-2), 81-85. [In Ukrainian].

2. Bondar, A. O., Vakoliuk, V. D., \& Orlov, O. M. (2002). Suchasni tekhnolohii vyroshchuvannia podilskykh dibrov. Lisivnytstvo $i$ ahrolisomelioratsiia, 101, 85-88. [In Ukrainian].

3. Hensiruk, S. A., Nyzhnyk, M. S., \& Kopiy, L. I. (1998). Lisy zakhidnoho rehionu Ukrainy. Lviv: Atlas, 407 p.

4. Kopiy, L. I. (1999). Osnovni aspekty rehionalnoi prohramy zbilshennia lisystosti zakhidnoho rehionu Ukrainy. Scientific Bulletin of UkrSFU, 9(8), 134-140.

5. Kopiy, L. I., Kopiy, S. L., Chaplyk, O. A., \& Lentiakov, V. V. (2012). Sposoby vidtvorennia dubovykh lisostaniv Zakhidnoho Lisostepu Ukrainy. Forestry, Forest, Paper and Woodworking Industry, 38, 20-29.

6. Kopiy, L. Y. (1987). Estestvennoe vozobnovlenye duba chereshchatoho v uslovyiakh Zapadnoi Lesostepy y eho yspolzovanye dlia vosstanovlenyia dubrav Abstract of Candidate Dissertation for Architectural Sciences. (06.03.03 - Forestry and forestry, forest fires and fight against them). Minsk, $18 \mathrm{p}$.

7. Levchenko, V. V. (2004). Pryrodne nasinnieve ponovlennia u svizhykh dibrovakh odnorichnykh zrubiv Kyivskoi oblasti. Scientific Bulletin of the National Agrarian University, 71, 58-64. [In Ukrainian].

8. Levchenko, V. V. (2004). Pryrodne nasinnieve ponovlennia u svizhykh dibrovakh na odno - shestyrichnykh zrubakh Kyivskoi oblasti. Scientific Bulletin of the National Agrarian University, 70, 283-289. [In Ukrainian].

9. Levchenko, V. V. (2005). Vplyv osvitlenosti na kilkist i yakist pryrodnoho nasinnievoho ponovlennia pid polohom lisu $\mathrm{u}$ svizhykh dibrovakh Kyivskoi oblasti. Scientific Bulletin of the National Agrarian University, 83, 192-202. [In Ukrainian].

10. Meshkova, V. L. (2011). Dynamika sanitarnoho stanu dubovykh derevostaniv u livoberezhnomu lisostepu Ukrainy pislia provedennia lisohospodarskykh zakhodiv. Forest Journal, 1, 28-32. [In Ukrainian].

11. Rumiantsev, M. H. (2015). Osoblyvosti poperednoho ponovlennia derevnykh porid $\mathrm{v}$ umovakh sukhoi klenovo-lypovoi dibrovy Livoberezhnoho Lisostepu. Forestry and agroforestry, 126, 9298. [In Ukrainian].

12. Rumiantsev, M. H., Solodovnyk, V. A., Chyhrynets, V. P. et al. (2016). Osoblyvosti formuvannia i vidtvorennia pryrodnykh lisostaniv duba zvychainoho Livoberezhnoho Lisostepu Ukrainy. Forestry and agroforestry, 128, 63-73. [In Ukrainian].

13. Sendonin, S. Ye. (2006). Pryrodne nasinnieve ponovlennia pid polohom styhlykh nasadzhen u svizhykh dibrovakh Cherkaskoi oblasti. Scientific Bulletin of the National Agrarian University, 96, 64-69. [In Ukrainian].

14. Sendonin, S. Ye. (2006). Pryrodne nasinnieve vidnovlennia na zrubakh u Pivdenno-zakhidnomu Lisostepu Cherkashchyny. Forestry, Forest, Paper and Woodworking Industry, 31, 170-175. [In Ukrainian].

15. Sendonin, S. Ye., \& Nazarenko, N. M. (2007). Doslidzhennia pryrodnoho ponovlennia u svizhykh dibrovakh Pravoberezhnoho lisostepu z vykorystanniam HIS. Scientific Bulletin of the National Agrarian University, 106, 45-50. [In Ukrainian].

16. Strochynskyi, A. A., \& Kashpor, S. M., \& (Scientific Ed.). Unifikovana systema bonituvannia lisovykh nasadzhen: lisotaksatsiini normatyvy. Kyiv: NAU, 8 p.. [In Ukrainian].

17. Tkach, V. P., Kobets, O. V., \& Rumiantsev, M. G. (2018). Use of forest site capacity by forests of Ukraine. Forestry and Forest Melioration, (132), 3-12. https://doi.org/10.33220/1026$\underline{3365.132 .2018 .3}$ 
18. Tkach, V. P., Kobets, O. V., \& Rumiantsev, M. H. (2019). Condition and productivity of oak stands in Ukrainian Steppe. Forestry and Forest Melioration, (134), 13-23. https://doi.org/10.33220/1026-3365.134.2019.13
19. Tkach, V. P., Luk'yanets, V. A., Tarnopylska, O. M., \& Rumyantsev, M. G. (2018). Ways for reconstruction of noncommercial coppice oak stands in Left-bank Forest-steppe zone. Forestry and Forest Melioration, (132), 48-56. https://doi.org/10.33220/1026$\underline{3365.132 .2018 .48}$

A. A. Novak, S. L. Kopiy, I. V. Fizyk

Ukrainian National Forestry University, Lviv, Ukraine

\section{FOREST TAXATION STRUCTURE OF OAK FOREST STANDS OF} THE WESTERN FOREST STEPPE

The peculiarities of distribution of oak stands in the Western Forest-Steppe of Ukraine are analyzed in the work. The analysis of forest typological structure of stands with the participation of common oak in the conditions of the Western Ukrainian forest-steppe forestry district is performed. The structure of oak stands areas in the context of edatopes and forest types has been studied; their quality and completeness, composition and origin have been identified as well. The largest share of oak forest stands in the Western Forest-Steppe is found to be concentrated in fertile site type conditions $-79.3 \%$. Fairly fertile site types of forest vegetation conditions make up $20.5 \%$ of the area of oak stands. According to the degree of soil moisture, common oak in the Western Ukrainian foreststeppe forestry district prefers fresh conditions, where $65.6 \%$ of oak forests in the region are concentrated. In total, common oak is involved in the formation of 47 forest types in the study area, in 19 of which it is considered to be type-forming species. Most oak stands are of the first class of stand quality (49.9\%), and a significant part (35.7\%) of plantations is of the second class. The average stand quality is estimated as I.3. Oak stands stocking in the Western Forest-Steppe, for the most part, is medium-sized. Their average stocking is 0.73 . Stand stocking of the largest share (39.3\%) is 0.7 . Medium-sized stocking of stands in total amounts to $55.9 \%$ of the total area of oak forest stands in the study area. The share of high-density stand stocking in the complete structure of oak stands of the Western Ukrainian forest-steppe forestry district is $42.3 \%$. Furthermore, plantations, where oak constitutes only 4 units i.e. $20 \%$ of the total area, are found to dominate in the Western Forest-Steppe. The average ratio of oak share in plantations is 5.7. The age structure of the oak forests of the Western Forest-Steppe is revealed to be uneven, with a significant predominance of medieval stands $-54.2 \%$. Mature stands occupy only $8.0 \%$ of the area of oak forest stands of the Western Forest-Steppe. The average age of oak stands in the Western Ukrainian forest-steppe forestry district is 61.2 years. Furthermore, artificial plantations are found to prevail in the studied region $(69.5 \%$ ), usually created by planting forest cultures. Oak stands of natural seedling-origin make up $27.3 \%$ of the area of oak forests of the Western Forest-Steppe, natural vegetative-regenerated origin stands amount to $3.2 \%$. gin.

Keywords: common oak; forest typological structure; forest valuation features; forest types; quality; stocking; composition; ori- 